\title{
The Leverage Status Quo and Risk Prevention of China's Real Economy
}

\author{
Dianhong Zheng ${ }^{1, a}$
}

\author{
${ }^{1}$ School of Humanities and S.S.\&Law, Harbin Institute of Technology, Harbin150001, China \\ azdh.086@163.com
}

Keywords: Status Quo, The Real Economy, Risk

\begin{abstract}
The leverage ratio of Chinese real economy has soared since 2008,especially among the government departments and nonfinancial corporate sectors. High economic leverage has reduced the utilization rate of real economy debt investments. As a result, corporate accounts receivable have increased and face a great risk of bankruptcy. And the high leverage in the real economy also affects the stability of the financial system and society. Using the experience of other countries for reference, China's deleveraging process should be laid out early, insisting on structural reforms as a permanent solution. At the same time, as the real economy is deleveraging, the financial sector should take the initiative to coordinate and the non-financial sector should adopt differentiated strategies.
\end{abstract}

\section{Introduction}

At present, the leverage ratio of China's real economy is much higher than the average level of emerging markets, which is comparable to that of advanced economies. Among the three sectors of the real economy, the high leverage risk of government departments and non-financial corporate sectors is particularly prominent. And local government debt has been growing at a rapid rate, with many hidden debts and a large risk of default among government debt. As for the leverage of nonfinancial enterprises, which accounts for the largest proportion of the total leverage of the real economy, especially after 2008, which has increased significantly and is now higher than Japan and the euro area. The high leverage of the real economy has seriously threatened the security and stability of the real economy and financial system, which has aroused widespread concern of the government.

The main parts of this article are the second, third and fourth parts. The second part mainly analyzes the status quo of the total leverage of the real economy, which is illustrated by the three departments of the family department, government department and non-financial enterprise department. The third part discusses the risks of high leverage of the real economy on the real economy, the financial system, and social stability. The fourth part mainly analyzes the enlightenment of foreign experience on China's deleveraging process.

\section{The Status Quo of The Leverage of The Real Economy}

There are two levels of leverage ratio: microscopic and macroscopic. This article analyzes the level of leverage at the macro level. At the macro level, leverage mainly refers to debt-to-income ratio and is used to measure debt sustainability. Since GDP is theoretically equal to total domestic income, the ratio of total debt to GDP in a sector of the macro economy is used as an indicator of leverage. From 2002 to 2017, according to BIS data, entity leverage ratios have shown an upward trend both in developed and emerging markets, and the overall leverage ratio of advanced economies is approximately twice that of emerging markets.

Since 2008, the total leverage of China's real economy has soared. And it is now at a level comparable to that of developed economies and much higher than the average level of emerging markets. In the second quarter of 2017, China's real economy leverage ratio was $255.9 \%$, which meant that China's debt reached $255.9 \%$ of GDP. In the same period, the real economy leverage ratio of the United States was $249.5 \%$, the euro zone was $262.8 \%$, Japan was $373 \%$, and the emerging market was $190 \%$. After the economic crisis in 2008, the rate of increase in China's leverage rate accelerated, from $144.7 \%$ in 2008 to $255.9 \%$ in 2017, with an average growth rate of $6.54 \%$ per year. 


\section{Comparison of the total leverage of the real economy (Unit : percentage)}

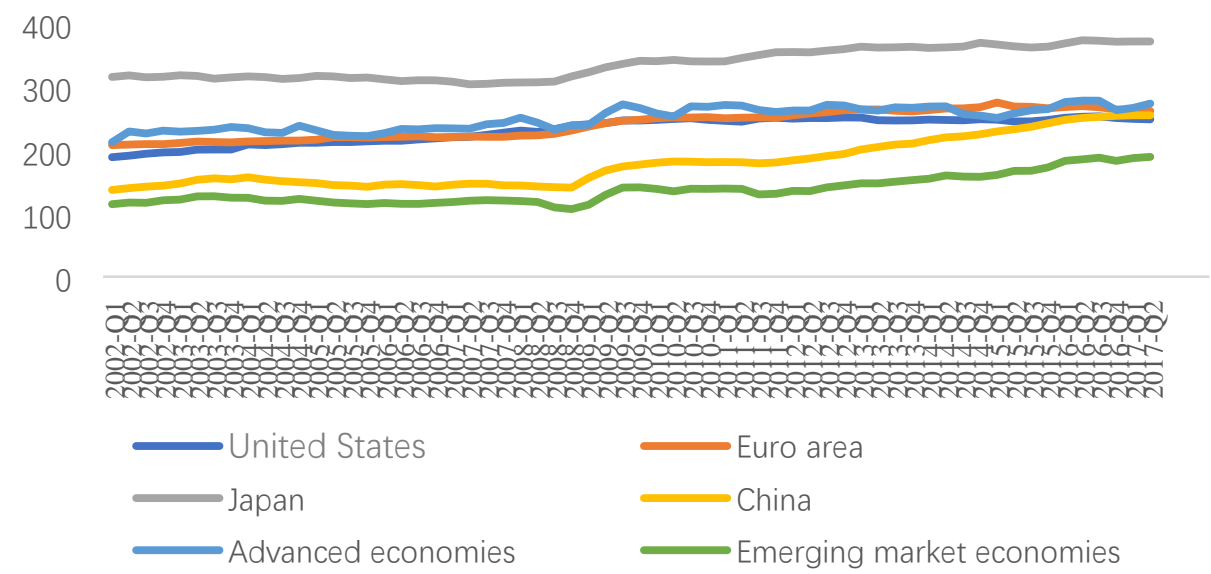

Data Sources: BIS

Entity debt usually consists of three parts: household debt, government debt, and non-financial corporate debt. In the following parts, we will study the leverage of the above three parts separately.

\section{1 household debt}

\section{The Levarage Ratio of Household}

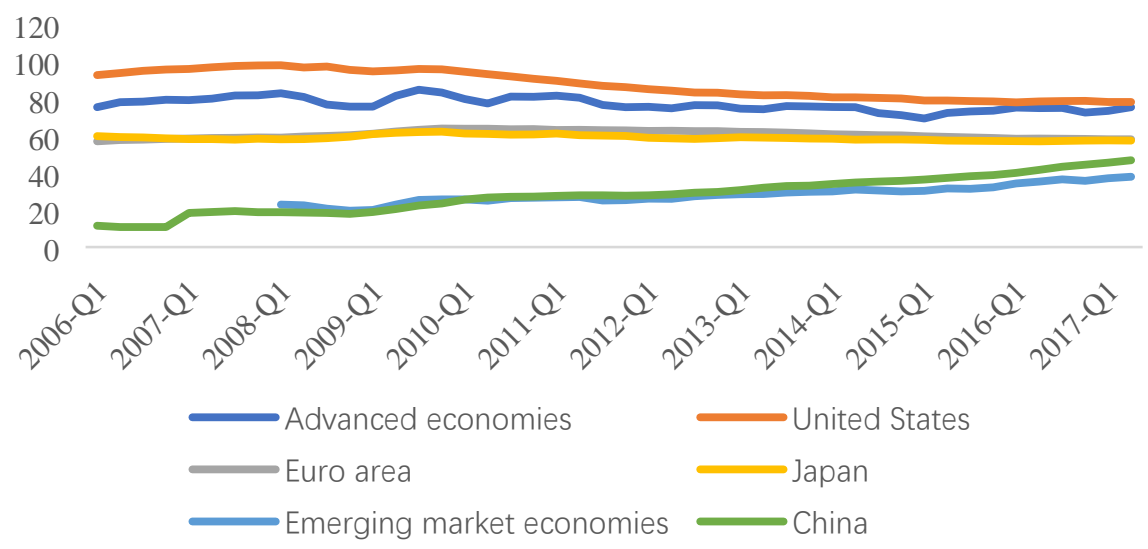

Data Sources: BIS

As can be seen from the above figure, the leverage ratio of the household sector in developed economies is significantly higher than that of the household sector in emerging markets. And the leverage ratio of the U.S. household sector is higher than that of the advanced economies. Moreover, the high level of leverage in the household sector reflects the advanced consumer propensity of the advanced economies. After the subprime mortgage crisis in 2008, the economy of the United States was low and market sentiment was not optimistic, and as a result, the level of leverage in the household sector had declined.

The overall level of leverage in China's household sector has been steadily rising. In the second quarter of 2017, resident debt reached $46.8 \%$ of GDP. From the perspective of the family sector, household leverage is mainly used for consumption and investment. In recent years, China's economy has generally improved. On the one hand, while residents' income levels have increased, their willingness to increase leverage has increased. So the residents are willing to borrow money to meet better consumer demand and investment. On the other hand, in the traditional Chinese conception, the house is a must-have item, and the excessive increase in house prices is an important reason for the increase in leverage of the family department. From an external perspective, the improvement of the credit information system and the emergence of various borrowing channels have made it possible for the family to borrow. As the personal credit market in China is getting better ,there are plenty of system except the credit system of the People's Bank of China, platforms such as Sesame Credit and 
Tencent's credit have entered the personal credit area. Furthermore, with the application of big data and artificial intelligence, users' images can be better constructed and identify risks. Alipay and cash loan platforms have provided more options for families to increase leverage.

Although the overall leverage level of the Chinese household sector is still lower than that of the United States, the euro zone and other advanced economies, the high growth rate in recent years deserves vigilance. Since the financial crisis of 2008, the U.S. household sector has been constantly deleveraging, while the Chinese family sector has been constantly increasing leverage. Considering that China's household population leverage is mainly concentrated in the urban, especially in certain first- and second-tier cities, the leverage ratio of China's household sector is not low.

\subsection{Government Department}

\section{The Levarage Ratio of Government Department}

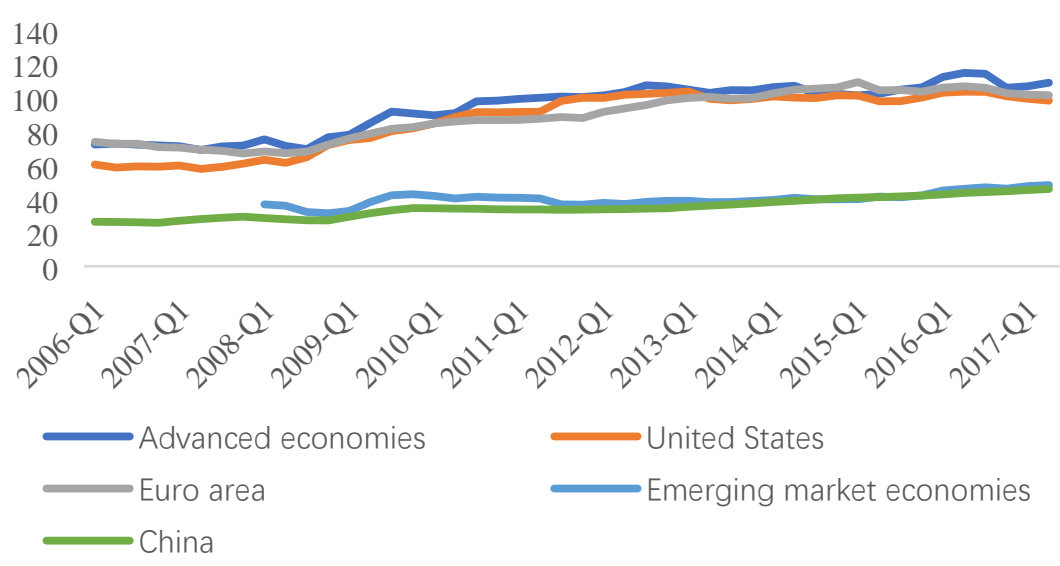

The leverage ratio of China's government departments has increased during recent years, but the overall situation is not high. And in the second quarter of 2017, it was 45.7\%, which was far lower than the $108.6 \%$ of developed economies, but the Chinese government has a relatively high hidden risk. Judging from the debt category, among the Chinese government debt, local government debt has grown rapidly and accounted for a large proportion. After the financial crisis in 2008, 4 trillion Yuan was planned to be implemented, and the market had sufficient liquidity. And additionally, because of the lack of supervision, the explosive growth of shadow banking and the loopholes in the local government fiscal system caused the growth of local government debt. What's worse, local debt has many investments in infrastructure construction, and projects with low returns have failed to cover principal and interest income, and the risk of default has increased, adding to the market's systematic risks.

\section{3 non-financial corporate}

\section{The Levarage Ratio of Non-financial Corporate}

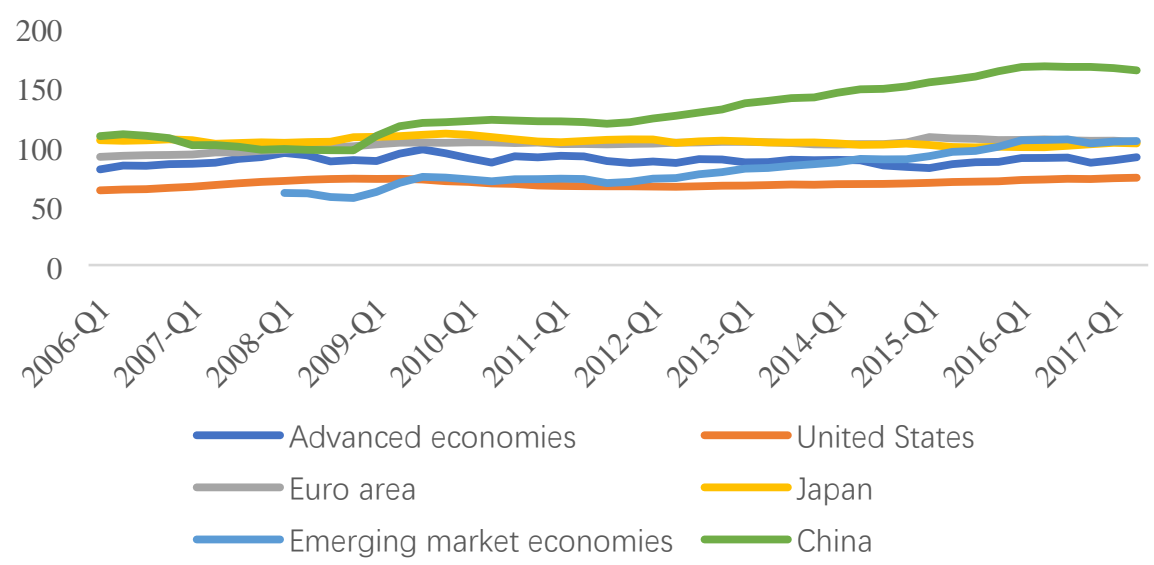

The non-financial corporate sector in China has a relatively high leverage and accounts for a large proportion of the entity's leverage. In the second quarter of 2017, the non-financial corporate leverage 
ratio was $163.4 \%$, accounting for $63.85 \%$ of the entity's leverage ratio, while the emerging markets in the same period were $104.1 \%$ and $54.8 \%$, respectively, and the developed economies were $90.5 \%$ and $38 \%$ respectively.

Over the past 10 years, the non-financial enterprises in China have experienced rapid growth in leverage, especially after 2008, the leverage ratio of China's non-financial corporate sector has surpassed that of Japan and the euro area, and has significantly increased. Which is closely related to the government's policy of stimulating economic development in 2008 and encouraging companies to increase production capacity and leverage. In 2016, the leverage of the non-financial corporate sector declined slightly, and the macro-supply-side structural reforms began to show results. With the deepening of state-owned enterprise reforms, the phenomenon of high leverage in the non-financial corporate sector is expected to ease.

\section{The Risks of High Leverage of The Real Economy}

Through the above analysis, it can be seen that the leverage ratio level of the Chinese real economy is relatively high, and the leverage ratio between the non-financial enterprises and the government departments has grown faster, which reflects that the unreasonable corporate financing structure and internal imbalances in the real economy. Furthermore, the implicit debt in government debt is significant and repayment pressure is high. And these problems will induce real economic risks, and then lead to financial systemic risks and social instability risks through the transmission mechanism.

3.1 The Risks of The Real Economy

3.1.1 Debt investment efficiency is reduced, and funds are mismatched between the real economy

High leverage will lead to low corporate debt investment. When a highly leveraged company is in a financial dilemma, usually it will maintain normal operations by borrowing new debts and returning old debts, which reduces the investment efficiency of enterprises. Debt investment efficiency refers to the flow of investment created by a unit of stock debt. Companies borrowing new debt nominally increased the amount of debt, but did not bring in new investment. There are many new debts that are used to repay the interest. As a result, the new investment created by the new liabilities has decreased, that is, the investment efficiency of funds has declined. In addition, if banks continue to borrow funds into these enterprises, these products are not competitive and financials are not sustainable, and zombie companies will use up credit resources, as a result, funds will continue to be deposited in overcapacity enterprises. However, some qualifications are good and they have real enterprises that have the willingness to invest have not been able to obtain sufficient funds, resulting in misallocation of funds in the real economy and irrational use of resources.

\subsubsection{Corporate Bankruptcy Risk}

High leverage is likely to put many companies into bankruptcy. When companies cannot obtain external funds to get out of financial difficulties, they will create solvency risks, thus, companies will go bankrupt because they are unable to repay their debts on schedule. And under the "financial accelerator" mechanism, when the economy is in a downturn, as asset prices decline, the decline in the net value of corporate assets will also amplify the impact on their investment and accelerate the speed of bankruptcies.

\subsubsection{Slower Currency Circulation, More Receivables}

High leverage has changed the micro-foundation of monetary policy transmission and distorted the effect of monetary policy transmission. According to the formula MV=PT, when the total amount of money increases and the GDP growth rate declines, it will inevitably lead to a decline in the currency circulation rate. At present, China's economic growth has slowed down, and the rate of currency issuance has not been significantly reduced, which will inevitably lead to a decline in the velocity of currency circulation. What's worse, it will lead to a decrease in the proportion of operating cash flows of enterprises and an increase in accounts receivable, which will highlight the problem of the triangular debt. 


\subsection{The risk of the financial system}

Judging from the empirical research experience of systematic risks and leverage ratios, systematic risks and leverage ratios are often positively correlated. The "Threshold Effect Hypothesis" holds that there is an obvious "threshold effect" on the effect of leverage on systemic risk, which says when leverage exceeds the threshold, economic growth begins to decline, and systemic risk increases. The "inverted U-type hypothesis" holds that there is an "inverted U-shaped" nonlinear relationship between leverage and systemic risk. The "5-30 rule of thumb" believes that if a country's credit size/GDP growth rate exceeds $30 \%$ in five years, the country may face a more serious financial crisis. Leverage is a leading indicator of the financial crisis. When the country's debt reaches a certain threshold, systemic risks increase.

With the constant cultivation and development of the financial system, there is a close connection between the real economy and the financial system, forming a macroscopic transmission mechanism for leverage risk from the entity sector to the financial sector. Banks are the main source of funds for the real economy sector, especially those state-owned enterprises with excess capacity. And when the high leverage of the real economy triggers solvency risk, the quality of bank mortgage loans will decline. What's worse, if banks continue to provide funds for these companies to help them get out of financial difficulties, then the bank's non-performing loan ratio will further increase. According to the monitoring indicators of the China Banking Regulatory Commission in the fourth quarter of 2017, the balance of non-performing loans of commercial banks was 1.71 trillion Yuan, the non-performing loan ratio was $1.74 \%$, and the balance of concern loans was 3.41 trillion Yuan, which was twice than that of non-performing loans. In addition, the risk of individual banks will be amplified by the interbank contagious mechanism, which will eventually lead to the full-scale outbreak of systemic risks.

\subsection{Social instability risk}

The so-called social instability risk refers to the possibility that the social relationship will be deteriorating due to the change between assets and liabilities and the adjustment of interests brought about by the post-repair.

First of all, high leverage threatens the stability of the economic and financial system. Once a crisis erupts, it will cause economic contraction, bankruptcy, destruction of people's production and life, and social conflicts.

In addition, government and corporate departments will have all kinds of thorny problems in the process of de-leveraging, If they are handled improperly, it will also provoke social instability risks. As far as government departments are concerned, if we reduce leverage through fiscal spending cuts, especially social welfare and people's livelihood, public dissatisfaction will be caused. And if the debt is diluted by additional currency, there may be serious inflation and induce social instability. As for the corporate sector, some industries will fall into the "debt-deflation" cycle. The industries with debt problems in China are mostly happened in overcapacity and mid-to-high-end companies at the production end. The profits of these enterprises have been greatly reduced, and the problem of financial leverage has been magnified, besides, there may be the risk falling into the "debt-deflation" cycle.

\section{The Enlightenment of Foreign Experience on China's Deleveraging Process.}

In terms of theoretical research on deleveraging, Ray Dalio's research shows that the reason why the deleveraging outcome is good or bad depends on the strength and the speed of debt reduction, austerity measures, wealth transfer, and debt monetization. All these four measures can reduce the debt/income ratio, but they have different effects on inflation and economic growth. Debt reduction and austerity measures have deflation and suppression attributes, while debt monetization has inflation and stimulus attributes. The key to the outcome of deleveraging is the proportion of these measures mixed together. Generally, deleveraging goes through three phases: The first phase is "terrible deflation and deleveraging." At this stage, there was only debt reduction and spending squeeze, and no debt monetization. During this period, the declining of private-sector credit and liquidity crunch will lead to a decline in demand for goods, services and financial assets, and a 
decline in economic vitality. At the same time, debt defaults and restructuring will hit the market and trigger a leveraged lender's liquidity crisis. The second phase is "wonderful deleveraging." At this stage, benefited from the debt monetization, raising the nominal growth rate above the nominal interest rate and using currency devaluation to offset deflation, then the debt/income ratio will decline, and as a result, economic activity will recover, and financial asset prices will improve. The third stage is "terrible inflation deleveraging." When money is printed excessively and the other three measures are used less frequently, the currency depreciation is too severe and it will occur "terrible inflation deleveraging"

Looking at the specific measures for deleveraging after the US subprime mortgage crisis in 2008, before the financial crisis, the real estate prices in the United States rose. And the financial departments issued home mortgage loans to the families and sold financial products to investors in the form of asset securitization. As a result, the debt ratio of those families and the financial sector rose rapidly. After the financial crisis, both the U.S. household sector and the financial sector experienced a deleveraging process and achieved remarkable results. For the household sector, deleveraging is mainly working through debt default. After the crisis broke out, real estate prices fell rapidly. Many families and departments were insolvent and had to choose debt defaults to recover property from banks. As far as the financial sector is concerned, on the one hand, it sells problem assets to the government under the framework of the Financial Relief Act with the core of "TARP," and at the same time, it substantially supplements capital by selling bank assets in the market. On the other hand, liquidity is injected into the market through large-scale asset purchase plans, and the stability of the banking system is enhanced through the purchase of mortgage-backed securities.

Combined with the above theoretical research and international experience, China's deleveraging can be inspired by the following aspects: firstly, China's deleveraging process should be planned early, strengthen top-level design, choose the proper time and gradual approach to deleverage in order to avoid systemic financial risks. From the perspective of international experience, high leverage is often accompanied with economic bubbles and systemic financial risks. The deleveraging in developed countries such as the United States and Japan has occurred after the financial crisis at a severe cost. China's current non-financial corporate sector has a relatively high leverage ratio, and it should seize the opportunity to take effective measures to achieve de-leveraging. Secondly, for nonfinancial corporate sector deleveraging, "differentiated" deleveraging should be adopted. Stateowned enterprises are divided into commercial and public welfare. For commercial state-owned enterprises, it's better to implement commercialized operations in accordance with the requirements of marketization, concentrating on supporting high-quality enterprises in the industry, surviving the fittest, and progressing in an orderly manner. For public welfare state-owned enterprises, if their leverage exceeds tolerance, they can be resolved through state-owned capital intervention. In addition, many measures are taken to reduce the company's operating costs and improve the company's debt solvency. Thirdly, in the process of deleveraging, the financial sector should take the initiative to coordinate, and the financial sector needs to establish a bad debt stop loss response mechanism as soon as possible. If necessary, even a special bad debt bank can be set up to dives bad assets, and the capital can be replenished in time to improve the quality of the balance sheet. At the last, structural reform is the permanent solution of de-leveraging. In the process of de-leveraging, China needs to further advance structural reforms, speed up the elimination and withdrawal mechanism, allow debt-losing companies to default on debts and bankruptcy, and effectively guide the reconfiguration of resources to high-quality industries and enterprises. What's more, broaden diversified financing channels for enterprises, develop multi-level capital markets, and increase the proportion of direct financing.

\section{References}

[1] Ji Min, Yan B. Y., \& Li H. J. Leverage Structure, Level and Financial Stability: Theory and Empirics [J]. Journal of Financial Research. 2017(2):11-25

[2] Ma Y., Tian T., Ruan Z. Y., et al. Financial Leverage, Economic Growth, and Financial 
Stability[J] Journal of Financial Research. 2016(6):37-51

[3] Chen W. D., Xiong Q. Y. The International Comparison and Countermeasures of the Leverage Status of China's Non-financial Cor [J] International Finance Research 2017, 358(2):3-11

[4] Gou W. J., Yuan Y., \& Qi X. Leverage and Systemic Risk Contagion Mechanism: An Analysis Based on CCA Model [J]. Journal of Financial Research. 2016(3):74-91.

[5] Ma J. T., Dong X. J., \& Shi H. X. Chinese Leverage Ratio and Systematic Financial Risk Prevention[J] Finance \& Trade Economics, 2016, 37(1):5-21.

[6] Yi Y. China's Deleverage: An Analysis based on international experience [J]. Journal of Financial Research. 2016(7):86-88

[7] Dalio R. An In-Depth Look at Deleveragings. Bridgewater. 2012:1-31 